Bu makaleye atıfta bulunmak için/To cite this article:

AYAR, Z. (2021). Integrating The Mark on the Wall into an EFL Lesson to Teach Reading and Vocabulary.

Atatürk Üniversitesi Sosyal Bilimler Enstitüsü Dergisi, 25 (4), 1793-1808.

\title{
Integrating The Mark on the Wall into an EFL Lesson to Teach Reading and Vocabulary
}

Zülal $A Y A R^{(*)}$

\begin{abstract}
As the literature strikes interest and arouses the curiosity of learners, it is widely acknowledged that it has an undeniable impact on language education. In this sense, a lesson plan was developed focusing on the reading skill and vocabulary, and aimed at getting learners to discuss and make a critical analysis of a story. Accordingly, Virginia Woolf's one of the wellknown short stories, 'The Mark on the Wall' was incorporated into the plan as an intensive reading resource. In light of constructivism theory and eclectic method, this plan was designed for the instructors teaching English to learners enrolled in the English philology department and taking one-year compulsory preparatory education at schools of foreign languages. As it is grounded upon synchronization, orchestration and symbiotic existence of the language teaching techniques, this short course plan would stimulate students' self-discovery, creativity, learner-centeredness, and reading analyses via pair-work and group activities.
\end{abstract}

Keywords: ELT, English literature, literature in language education, teaching reading, teaching vocabulary.

\section{Okuma ve Kelime Bilgisi Öğretimi için The Mark on the Wall adı Eserin İngilizce Dersinde Kullanımı}

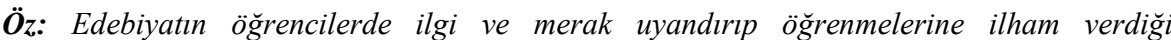
düşünüldü̆̈̈üde dil eğitiminde yadsınamaz bir etkisi olduğu açıktır. Bu gerçeği dikkate alarak, ögrencilere kısa öykü üzerinde eleştirel incelemeler yapma firsatı sunan aynı zamanda kelime ve okuma becerisine ağırlık veren bir ders planı geliştirilmiştir. Bu amaçla, Ingiliz edebiyatının en önemli eserlerinden biri olan Virginia Woolf'un 'The Mark on the Wall' adlı kısa öyküsü 'yoğun okuma' kaynağı olarak plana dâhil edilmiştir. Plan, yapılandırmacılık kuramı ve eklektik yöntem ışığında tasarlanmıştır. Bu program, yabancı diller yüksekokulunda, bir yıl zorunlu hazırlık eğitimi alan 17 yaş ya da üzerindeki İngiliz Edebiyatı bölümü ögrencilerine ileri seviyede İngilizce dersi veren ögretim görevlileri için hazırlanmıştır. Dolayısılyla, çalışmanın geliş̧tirilmesindeki asıl sebep, akademik personele pratik ve kolayllkla uyarlanabilen iki saatlik yoğun bir ders programı sunmaktır. Böylelikle, dil ögretim tekniklerine dayalı bu ders planını, öğretim görevlileri detayl hazırlık yapmadan derste direkt uygulayabileceklerdir. Örnek planın ardından gelecek çalışmalara yön verecek tavsiyelere de yer verilmiştir.

Anahtar Kelimeler: Dil eğitiminde edebiyat, İngiliz dili eğitimi, İngiliz edebiyatı, kelime ögretimi, okuma becerisi ögretimi.

Makale Gelis Tarihi: 31.07 .2021

Makale Kabul Tarihi: 16.12.2021

DOI: $10.53487 /$ ataunisosbil.976895

\footnotetext{
*)Öğretim Görevlisi Dr., Ankara Üniversitesi Yabancı Diller Yüksekokulu (e-posta: ayarz@ankara.edu.tr) (D) ORCID ID. https://orcid.org/0000-0002-9029-7164

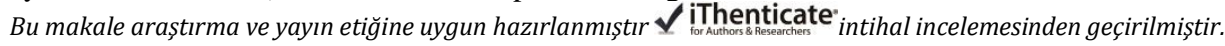




\section{Introduction}

As declared by Hall (2005), literature is one of the pivotal resources to be referred to in language education considering that it will help students expand the vocabulary pool by exposing them to daily dialogues and literary language as well as increasing awareness of linguistic domains. However, to give a more comprehensive and much clearer portrait of how literature has turned out to be an essential figure in foreign language education and leveraged English language teaching (ELT), initially a brief review must be introduced at that point.

In the late $18^{\text {th }}$ century when Grammar Translation Method (GTM) evolved from the Classical method and was widely acclaimed in language teaching, it was the golden age of literature because of the word-for-word translations of literary passages to and from the learners' native language (Larsen-Freeman \& Anderson, 2011). Nevertheless, the emergence of some communicative based methods (e.g. the Audio-lingual Method, the Direct Method) brought discredit to GTM, which in turn adversely affected the integration of literature in language classes. The Communicative Language Teaching (CLT) paradigm shift, which appeared in the 1970s and gained a high reputation, even impeded welcoming literature in language teaching in the first place as its focal point was speaking. As such, Paran (2000) criticized that the role of literature within the mainstream of EFL was still not firmly established. Not until the 1980s, did the significance of using literature in foreign language teaching vivify again. Still, this time, dissimilar to its role in GTM, it would be a means to an end in terms of contributing to communicative competence and enhancing language development (Erkaya, 2005). Moreover, with the increasing popularity of educational pedagogy and the key concepts, such as internalization of the language (Elliot, 1990; Helton, Asamani \& Thomas, 1998), student-centeredness, creativity, and professional identity construction (Kramsch, 2009), literature has become more of an issue. Accordingly, social dialects, linguistic diversity, differences in accent and style have also accelerated ubiquitous learning through literature and it allowed for contextualized instructions. Taking this into consideration, a growing body of scholars (e.g. Choe \& Drennan, 2001; Hall, 2015; McKay, 2014; Myonghee, 2004; Naji, Subramaniam, \& White, 2019; Scott \& Huntington, 2007, to name but a few) have dwelled on the multifaceted advantages of literature in language studies since then.

Despite these aforementioned benefits, literature may still constitute a challenge for language teachers since it requires employing specific reading strategies at the right time and instigating learners to go through cognitive reading processes for comprehension. Consequently, it may turn out to be an ordeal through their lens, particularly when some other context variables in teaching have also been taken into account (Anderson, 1999). Additionally, this compelling practice would demand using other skills and sub-skills to make learners implement and manage self-assessment, self-discovery and creative ideas. As it cannot be regarded as an oversimplified task, teachers can be abstaining from executing methodical reading instructional strategies. Instead, they may prefer readily adaptable course materials without counting in the learners' language learning goals exhaustively. Nevertheless, as is underlined, the vital facet of thriving success in reading 
lessons necessitates contemplating how to leverage its teaching by resting upon modern techniques but shying away from the stereotypes. Regarding this stance in the paradigm of ELT, a lesson plan has been developed to create an appropriate reading resource for the learners.

The lesson has been designed by utilizing Virginia Woolf's short story The Mark on the Wall as a source of intensive reading. Integrating this text into the classroom proceeds from the fact that although numerous exercises, activities, and language-related games are based on this story on the Internet, there is no, if any, a formal and systematic study specifically using it in an EFL lesson. Additionally, another basic motive behind planning this study is to offer a practical and easily adaptable plan to the academic staff. Put it differently, the plan whose theoretical basis is rooted in the constructivist theory and the eclectic method has aimed to offer a practical lesson for lecturers teaching almost advanced level of English to students enrolled in the English literature department and studying one-year compulsory preparation class at schools of foreign languages. Therefore, it would allow students to practise the language for creative purposes (Kim, 2004) and to make use of its sources (Scott \& Huntington, 2007). Moreover, they would get used to creating opportunities for learning in line with their needs, objectives and inclinations instead of practising inauthentic materials to be competent at how to overcome language learning problems (Cook, 2008). In so doing, they would also perform interactions, critical and analytical thinking (Par, 2018), self-questioning, and make inferences, create a community of practice (Lantolf, 2000) besides improving their tolerance of ambiguity (Budner, 1962).

\section{Literature Review}

Reading skill requires not only linguistic knowledge but full knowledge of the word as well. To put it another way, a reader has to master the whole process of getting the meaning and comprehend this written code rather than fathoming the language alone. For that reason, the selection of correct reading materials into the course is a sine qua non issue in ELT. The essence and similarity of the reading text with the content, affinityseeking between the needs and the sources are hence of utmost importance to contribute learners to gain higher attainments from the lesson. It adumbrates that intensive reading strategies seem convenient in terms of drawing attention, improving linguistic competence, increasing autonomy, and providing interactive reading opportunities for learners to partake in the community of practice (Lantolf, 2000). Otherwise, it would result in abiding by conventional reading instructions which only attempt to check learner comprehension and teach sub-skills, such as grammar and vocabulary in a short text through intensive reading tasks. Thereby, the literary text as an intensive reading (Nation \& Macalister, 2020) and a language resource bringing real-world relevance to the course must be adapted with selective use.

In a similar vein, Cook (1983) strongly recommends intensive reading activities enriched with cultural elements by setting against the customary reading tasks which generally cannot go beyond imbuing learners with how to fulfil a limited function or do an information gap activity. Cook (2008) also acknowledges that our target audience is 
not ESL learners; hence they would not have enough competence to conduct the tasks in L2. Thus, broadening the horizon of learners with authentic materials (e.g. literary texts) would result in raising cultural awareness and increasing their proficiency by transferring, answering, condensing, extending and converting the language (Collie \& Slater, 1987; Kim, 2004; Paran, 2008; Scott \& Huntington, 2007). Moreover, the literary work will strengthen the willpower of learners. As Brown (2001) and Grabe (2009) correlatively remark, and Harmer (2007) espouses 'engage, study and activate model' to lend credence to that notion, the motivation and volition of learners would enhance when the literary text overlapped with their L2 goals. In short, print exposure will facilitate the development of L2 skills while students have been learning with fun (Koda, 2007; Tseng, 2010). Furthermore, as young adults are easily influenced by pop culture and social expectations, paying attention to the foregoing caveats of Cook $(1983,2008)$ will help to boost their intake.

As is well-known, reading instruction needs to be administered with pre-, while- and post-reading activities similar to the other basic language skills. Correspondingly, Brown (2001) suggests that introducing topics with skimming, scanning techniques and activating the appropriate schemata of learners can be carried out at the pre-reading stage through literary texts (see Rumelhart, 1980). Thereafter, presenting a wide range of reasons for learners to read, examining the author's sound reasoning, allowing for incidental vocabulary acquisition preceded by follow-up activities, such as writing exercises, can be conducted as while- and post-reading, respectively. This is because integrating reading with writing tasks will launch and advance reading cognition, and word recognition for vocabulary development (Hirvela, 2004; Kuze, 2015; Naji et al., 2019). This also leads us to the fact that vocabulary would appear as another essential matter in literary work (Pressley, 2002). The frequency of the words, the feasibility of associative learning, their appropriateness to be adapted in the word-building process, the memorability (Leclercq, 2002), compatibility for content (Call, 1985), co-occurrence and convenience to the text processing strategies (Carrell, 1983) need to be considered painstakingly while planning the lesson.

In fact, the primary rationale for implementing a literary text in language classes must be that it enables top-down and bottom-up processing to coalesce into one and help learners to uptake (Goodman, 1970). The bottom-up process can be acknowledged as a data-driven and skill-based approach on the grounds that conception could only be achieved by gathering the sum of the parts together. As to the top-down process, it would reinforce strategic approaches and extended thinking in a conceptual driven way. Hence, only if learners could be drawn into the same task, would they accomplish decoding the text, understanding content with both implied and literal meaning, learning stylistic peculiarities in the text, and managing cognitive skills by focusing on a specific genre. Similarly, Koda (1992) and Nassaji (2003) handle the reading skill in terms of cognitive development and characterize both higher-level and lower-level processes. Whereas the lower level comprises parsing, encoding and word recognition to manage fluency, the other appeals more to comprehension through inferences, control processing, interpretations, and strategic processing techniques to get the gist of the text (Sage, 1987; Spack, 1985; Stern, 1991). As a case in point, the rhetorical language within a specific 
discourse structure would foster higher-order thinking skills of learners, help them deduce meaning from the context, and lead them to refer to the word-formation process or use mind maps. As a consequence, automaticity and fluency will be accomplished through explicit and implicit learning so that the learners would be strategic and good readers (Grabe, 2009) in the end.

As for the current study, this plan was developed in consideration of the work by Morris (1972), who pioneered the current trend of using short stories as an intensive reading resource in English language classes. Accordingly, the researcher has considered the foregoing topic-specific pedagogical content knowledge for literary texts, the learners' pressing needs, and the necessity of a sample lesson plan covering The Mark on the Wall as the main course material. Finally, she has directly addressed the niche in the literature and created the plan aiming majorly at learners' reading and vocabulary growth.

\section{The Study}

A lesson heavily based on reading skills needs to be designed respecting the place of literature in EFL classes due to a set of distinct advantages it offers to language teaching beyond its linguistic diversity and language repertoire (Arıogul, 2001). To illustrate, it will develop an awareness of register and impede being exposed to literary vernacularization (Hall, 2015). To that end, this two-hour compact intensive language lesson is prepared in light of the post-method era, constructivism and eclectic approach similar to the work by Baştug and Broutin (2021). It has been offered to the English instructors delivering lessons at the upper intermediate level at schools of foreign languages. As the needs and aims of Turkish EFL learners in the field of English philology would greatly differ from the other students taking one-year preparation classes, the plan will address their field-specific knowledge. Furthermore, the current plan has aimed to acquaint learners with one of the most fundamental literary works in English literature (i.e. The Mark on the Wall) and accustom them to making a critical analysis of short stories.

\section{The Lesson Plan}

\section{A. Physical Environment}

Classical music in the background and three chrysanthemums will be procured to avoid the mediocrity of a traditional lesson. By the same token, the caveats of Jones (1980) and Lozanov (1978) have been considered in terms of using peripheral teaching aids and musicals aids besides physical properties to promote learning. The other reason for including these supplementary materials is their attributions in the movie, The Hours. 


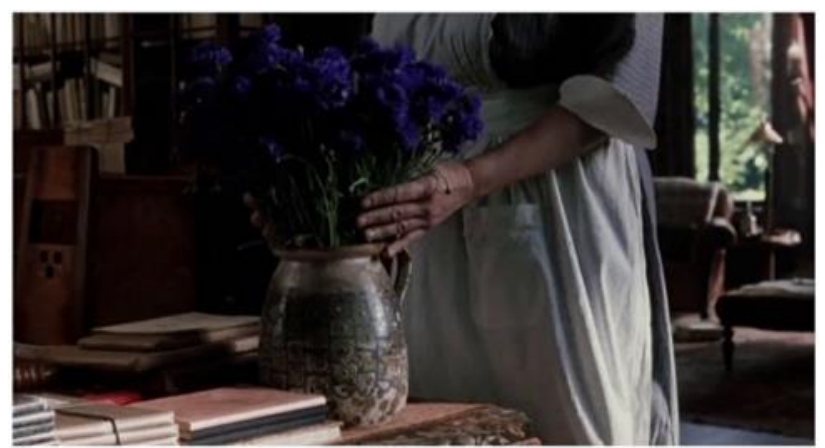

Figure 1. A scene from the movie

\section{B. Lead-in}

The lesson begins with a general discussion question to be posed to learners about the movies they were influenced by far the most. To personalize the reading instruction (Foerster, 1973), the teacher firstly shows a poster of her/his favourite movie The Hours in which the world-renowned actresses feature, such as Nicole Kidman, Julianne Moore, Meryl Streep. Then, s/he clarifies that the plot revolves around three women from different generations whose lives are somehow interconnected to one another. In the movie, Kidman represents Virginia Woolf who suffered from nervous breakdowns, bipolar disorder and depression. Due to these psychological problems, she feels that she was trapped in her house in England while trying to write a novel in the 1920s. Though Mrs Dalloway (a novel by Woolf) was addressed and analysed in The Hours, this movie has been intentionally exploited to introduce Virginia Woolf to the learners. Following the short presentation of her biography, the learners will be asked to reveal their predictions about her life, marriage and other characteristic features as the pre-reading activity. After encouraging learners to share estimations about the potential motives behind her suicide, the scene of her death in The Hours is shown so that they could dovetail it with the lesson.

\section{The literary text - The Mark on the Wall}

Initially, the teacher demonstrates the cover page of the story (Figure 2 below), The Mark on the Wall, without explaining its name in order to arouse learners' suspicion for the literary canon. This would then lead them to question the liaison between the image on the page and the target reading task rather than welcoming hand-me-down stories (Freeman \& Richards, 1996, p. 351). 


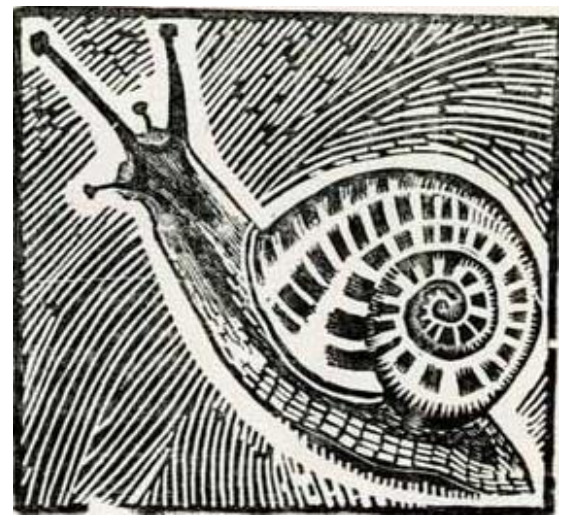

Figure 2. The cover page of the story

Then, one of the popular graphic organizers in language learning, the K-W-L chart will be incorporated into the lesson so that it would help learners to record their performances.

Table 1. K-W-L Chart

\begin{tabular}{lll}
\hline $\begin{array}{l}\text { What I Know about the } \\
\text { story? }\end{array}$ & What I Want to know? & What I Learned? \\
\hline 1. & 1. & 1. \\
\hline 2. & 2. & 2. \\
\hline 3. & 3. & 3. \\
\hline 4. & 4. & 4. \\
\hline 5. & 5. & 5. \\
\hline
\end{tabular}

In this way, it will resuscitate the lower level of cognitive functioning (Par, 2018; Spack, 1985). This is of pivotal importance as Schmidt (1990) denotes in his noticing hypothesis that learning necessitates attention, and the consciousness of the linguistic features to convert input into the intake.

Afterwards, the teacher shortly expresses the title of this intensive reading material and instigates learners to discuss which of the given words may appear in the story. S/he also starts to observe their tolerance of ambiguity to the unknown words as was underscored by Budner (1962).

- Colonels

- Archbishop

- River

- Giants

- $\quad$ Rose leaf
- Troy

- Shakespeare

- Heaven

- Botany

- Charles 
- Greeks

- Phantoms
- Melancholy

- War

Similarly, the proverb 'There is nothing certain, but the uncertain' is presented to harmonize their notions with the target words and activate the schema-relevant information (see Carrell, 1983; Rumelhart, 1980). After a short debate, s/he finally distributes the story and asks learners to read only the first paragraph individually in accordance with the skimming strategy (Brown, 2001). In consequence, the teacher makes them draw a mental picture to describe the setting within pairs. The aim herein is to monitor whether they could guess the main idea of the text by paying attention to the details (see Jones, 1980), such as the weather, atmosphere in the room, the author's actions throughout the story, the fireplace, chrysanthemums and the mark on the wall.

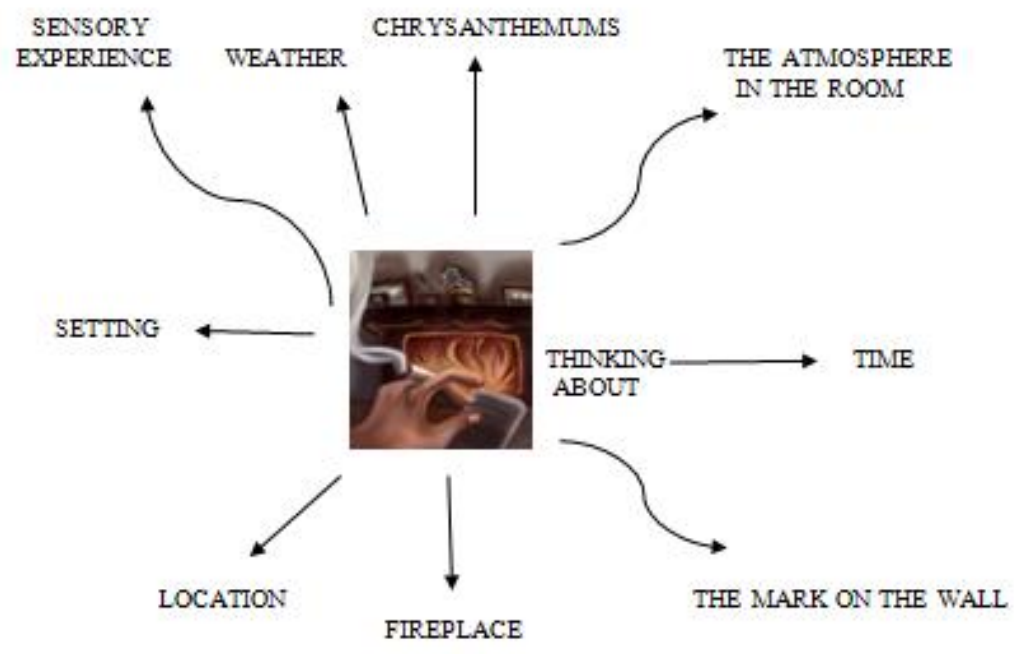

Figure 3. 'Thinking about ....' exercise (own elaboration of the author)

Based on the notion of Choe \& Drennan (2001), this while-reading activity will be accompanied by the exploitation of jigsaw reading through which all of the paragraphs in the story would be randomly assigned to groups in the class. Upon the distribution of the roles in class, the teacher firstly orientates learners to glance through the text, and then to scan it. After this, s/he asks some yes/no questions about the story allowing them to refer to a bilingual dictionary or thesaurus as is suggested in critical reading strategies (Par, 2018; Sage, 1987; Stern, 1991) while playing classical music in the background. The learners will be also encouraged to note down the significant points and underline or highlight any unknown words to determine their meanings using IDEAS form with different types of context clues (see Leclercq, 2002). 
Table 2. IDEAS

\begin{tabular}{lll}
\hline & Context Clues & Examples \\
\hline $\mathbf{I}$ & Inference & $\ldots \ldots \ldots$ \\
\hline $\mathbf{D}$ & Definition & $\ldots \ldots \ldots$ \\
\hline $\mathbf{E}$ & Example & $\ldots \ldots \ldots$ \\
\hline $\mathbf{A}$ & Antonym & $\ldots \ldots \ldots$ \\
\hline $\mathbf{S}$ & Synonym & $\ldots \ldots \ldots$ \\
\hline
\end{tabular}

After they finished reading their assigned sections, the students work collaboratively exchanging their knowledge with the other group members to understand the story thoroughly. In what follows, the teacher hands out six extracts from the story so that the learners can put the whole text in chronological order. Therefore, their sustained attention would also avail memorability of the language in the main as well as enhancing the retention of linguistic features with repeated acts of qualitative connections in longerterm memory (Carrell, 1983; Leclercq, 2002).

In the second round of the lesson, they will be able to respond to some WH questions and the concept checking questions, which is in tune with the reader-response approach (Tompkins, 1994):

1. Describe the room in as much detail as possible.

2. Why do you think the author dwells on the estimation that the minute figure must be a fraud?

3. What does she liken to the life and afterlife? Why?

4. What might be the author's reasons for talking against the old inhabitants of the house? What may this thought lead her to do?

As is seen, the teacher intends to make learners internalize the story and disclose their identities empathetically with hot cognition (Kramsch, 2009). Furthermore, studentstudent interaction and teacher asks-student response technique will be employed besides scrutinizing some linguistic forms according to the meaning-focused interaction (i.e. focus on form) to promote their inferences (Sage, 1987). Finally, they will be able to comprehend the story using these elicitation techniques.

Subsequently, the learners examine the author's purpose and craft, and the historical context of this opus further to apprehend the panorama of the society at that time. Then, they will be ready to work on a detailed literary analysis. Initially, the plot would be examined with dot points as is shown below. Moreover, other literary devices will be included, such as literal occurrences, exposition, complication, climax, reverse, resolution, foreshadowing, and denouement. This would also bring along the orientation in the story, the leading character(s), and the register (Arığul, 2001; Hall, 2015). Furthermore, the features of the character(s), the theme, and conflict(s) are to be discussed and clarified at this point. These are all to foster higher-order thinking skills, increase cognitive engagement of the readers and self-direct their learning to build 
independence over the long haul (Koda, 1992; Nassaji, 2003). The given prompts below can be directly adopted:

1. The orientation tells us about

2. The problem first appeared as.......

3. The denouement supplies.......

Since the learners are not even freshmen at the faculty, they have some missing points in speech and language use. That is why, in order to plant the seeds of further literary studies, they will be guided ('scaffolding' in the Vygotskian term) to work on the styles in that genre. Some types of symbolism and figurative language, such as personification, will be also incorporated to read between the lines (Sage, 1987; Arığul, 2001; Spack, 1985; Stern, 1991). Having shed light on the essential elements, the class will design their unique analysis implementing the foundational conceptual pillars of the story structure by integrating top-down and bottom-up processing as Goodman (1970) and Kintsch (2005) have asserted. Only then would the teacher embolden learners to identify 'stylistic foregrounding' by adopting the community of practice approach (Lantolf, 2000). In the end, students will share their thoughts about the correspondence of literary terms in the text.

The outline will resemble this model (own elaboration of the author):

\section{Introduction (1st Paragraph)}

- The potential interface with the narrator, the mark on the wall, and the 'husband' figure,

- The chosen words (e.g. winter, knights, nature, death) and their associations with the mystery of life,

\section{Body Paragraph(s)}

- Leading characters (the narrator and her husband despite the lack of solid characterization),

- $\quad$ Protagonist and antagonist (the narrator and the mark on the wall),

- Exposition (the author's blank stare at the wall in a melancholic and pensive mood in the living room),

- $\quad$ Plot (the mark on the wall),

- Theme (cynicism and ambivalence towards the opposite sex, male-female roles, changes in life, freedom, civilization, and hidden realities),

- $\quad$ Point of view (first person),

- Climax (the interruption of her husband),

- Conflict and paradox (the mark on the wall and her callousness to inspect it),

- Foreshadowing (her death),

- Symbols (fire, trees, church, chrysanthemums, pale blue canisters, tombs),

- Metaphor (the author's life and her thinking style),

- Imagery (mark's appearance), 
- Irony (self-image)

- Allusions (a war, Shakespeare, Greece),

- Simile (ants carrying straw and swarming thoughts)

- Personifications (ants, brown paper parcels)

- Resolution (the mark as a snail),

\section{Conclusion Paragraph}

- The mark on the wall and her true-life experiences making deep marks on her identity

Having completed the analysis of this literary text, they will return to their K-W-L charts and complete the last column of this performance report (i.e. what I learned?). Following this, the teacher makes the students aware of the comments posted on the web forums by the story readers from all over the world as the post-reading activity (see Hall, 2015). S/he presents those ideas to the class as is shown in Appendix. Thereafter, $\mathrm{s} / \mathrm{he}$ reckons the references of Collie and Slater (1987) and Paran (2008) with regard to reinforcing the dynamic reasoning of learners for literary analysis. In that vein, s/he asks whose judgment(s) are majorly applicable, what points they have failed to distinguish or which seemingly frivolous details have turned out to be the peripeteia in the further phases. This will be conducted with Claim, Evidence, and Reasoning (CER) Model which requires learners to prove their claims throughout the discussion. At the end of this activity, they will post a positive or negative answer to these readers by revealing their claims about the posts.

Table 3. CER Model (own elaboration of the author)

\begin{tabular}{lll}
\hline $\begin{array}{l}\text { Readers' posts/ } \\
\text { comments }\end{array}$ & $\begin{array}{l}\text { Evidence (paraphrased } \\
\text { or taken from the text) }\end{array}$ & $\begin{array}{l}\text { Reasoning (explaining the } \\
\text { reasons for supporting the } \\
\text { reader's comments using } \\
\text { own words) }\end{array}$ \\
\hline$\ldots \ldots \ldots \ldots \ldots \ldots$ & $\begin{array}{l}\text { 1. The author expresses } \\
\text { that due to the male } \\
\text { dominance even in the } \\
\text { church, she does not } \\
\text { have the religious } \\
\text { belief the others might } \\
\text { have. }\end{array}$ \\
\hline$\ldots \ldots \ldots \ldots \ldots \ldots$ & $\begin{array}{l}\text { 2. In paragraph 11; the } \\
\text { narrator discusses the } \\
\end{array}$ \\
& $\begin{array}{l}\text { Whitaker's Table of } \\
\text { Precedency. }\end{array}$ \\
\hline &
\end{tabular}

Alternatively, they can write and post the claims that they have created using the CER model under a 24-minute video recording on YouTube. 


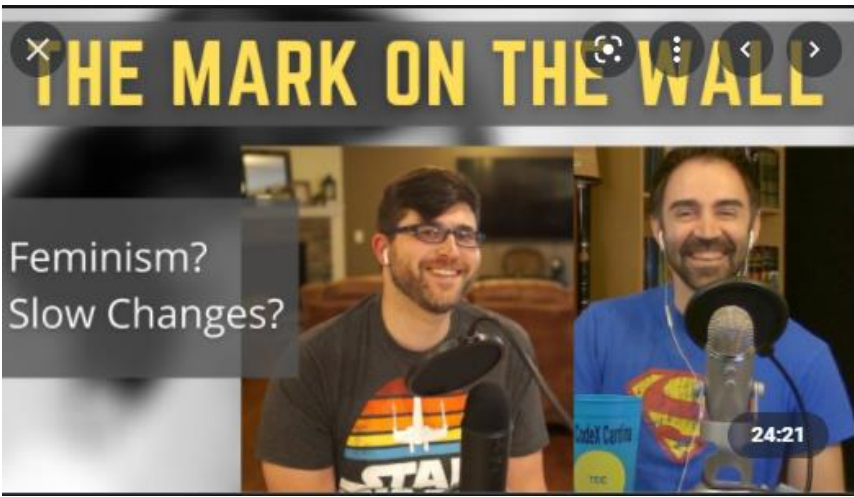

Screenshot 1. Video recording on YouTube (Retrieved from https://www.youtube.com/watch?v=WpWi1fPyP5E)

After the discussion and these posts, impromptu speech or soliloquy will be included to steer learners' attention to the superficially addressed points in the story, and spotlight the author herself and her husband from different aspects. These dramatic conventions ought to be stated in the plan thanks to the fact that they would trigger learners to interiorize the life in the 18th century and conjure up the mental picture of the author's senses, or the preoccupation of her thoughts from a broad line of inquiry (Elliot, 1990; Helton et al., 1998).

As for the writing, the written texts will be utilized as a formative assessment tool, yet it can also be included as a post-reading or back-up activity to enrich the lesson with integrated practices (Nation \& Macalister, 2020; Spack, 1985). Accordingly, the learners will be assigned to write their opinions about how to offer a different ending to the story and what they would liken the mark on the wall using the identical target words. Overall, it will be an opportunity to recapitulate the text spurring creativity and stressing the salient points through their reflections (see Hirvela, 2004). Moreover, the teacher will be able to assess their ability of transfer, reasoning in corollary, extending and replication (Kuze, 2015; Naji et al., 2019).

\section{Conclusion and Suggestions}

The plan has been designed to provide a practical lesson for English instructors giving literature lessons to the learners at the upper intermediate level. Additionally, it is developed to offer a course focusing on reading and vocabulary exercises and tasks to lead students to critical analysis. It would also encourage creativity, authenticityreadability balance, contextualization, and literary analyses via pair-work or group work activities. Moreover, refining the main points, making inferences and strong connections within text patterns, and maintaining the lesson with interactive practices have been highly reckoned. These techniques have all been adopted to attain the learners' goals, satisfy their expectations while engaging them with cognitive processing strategies in reading. Consequently, they will be able to establish individual strategies to promote 
reading and vocabulary competence. Furthermore, they would be engaged in the lesson through implicit instructions (Grabe, 2009; Harmer, 2007).

Since the learners are the beginners for analysing the literary work, only the reading skill has been remarkably manipulated in the plan, even though communicative activities are regarded to be the keynote address. However, it can also be cultivated by audio recordings or videos of the native speakers or the actresses taking part in the movie, which would improve their pronunciation. By the same token, vocabulary teaching practices via anaphoric cues, and rhetoric signal mechanism, and identifying organizational patterns in the text can be suggested for future directions to refer to in other lesson plans. Last but not least, the plan can be incorporated into a research design to unveil learners' vocabulary development and its effectiveness in their reading performance. As this is only a sample plan, its further contribution to the field can be investigated via empirical research by comparing the learners' attainments after the implementation process.

\section{References}

Anderson, N. J. (1999). Exploring second language reading. Boston: Thompson \& Heinle.

Arığul, S. (2001). The teaching of reading through short stories in advanced classes. (Unpublished master's thesis). Hacettepe University, Ankara.

Brown, H. D. (2001). Teaching by principle and interactive approach to language pedagogy. Longman Inc.

Budner, S. (1962). Intolerance of ambiguity as a personality variable. Journal of Personality, 30(1), 29-50. https://doi.org/10.1111/j.1467-6494.1962.tb02303.x

Baştuğ, D. \& Broutin, J. (2021). Advances in Language and Literary Studies (ALLS). 12(2), 13-20. http://dx.doi.org/10.7575/aiac.alls.v.12n.2.p.13

Call, M. (1985). Auditory short-term memory, listening comprehension and the input hypothesis. TESOL Quarterly, 19(4), 765-778.

Carrell, P. L. (1983). Some issues in studying the role of schemata or background knowledge in second language comprehension. Reading in a Foreign Language, 1, 81-92.

Choe, S. W. T. \& Drennan P. M. (2001). Analyzing scientific literature using a jigsaw group activity piecing together student discussions on environmental research. Journal of College Science Teaching, 30(5), 328-30.

Cook, V. J. (1983). What should language teaching be about? ELT Journal, 37(3), 229234. https://doi.org/10.1093/elt/37.3.229

Cook, V. J. (2008). Second language learning and language teaching. Hodder Education Publishers. 
Collie, J. \& Slater, S. (1987). Literature in the language classroom. A resource book of ideas and activities. Cambridge University Press.

Elliot, R (1990). Encouraging reader-response to literature in ESL situations. ELT Journal, 44(3), 191-198.

Erkaya, O. R. (2005). Benefits of using short stories in the EFL context. Asian EFL Journal, 8, 1-13.

Foerster, L. M. (1973). Personalizing reading instruction. Elementary English, 50(3), 461-463.

Freeman, D. \& Richards, J. C. (1996). Teacher learning in language teaching. U.K.: Cambridge University Press.

Goodman, K. S. (1970). Reading: A psycholinguistic guessing game. In H. Singer, R. B. Ruddell (Ed.), Theoretical models and processes of reading (pp. 497-508). Newark, DE: International Reading Association.

Grabe, W. (2009). Reading a second language moving from theory to practice. New York Cambridge University Press.

Hall, G. (2015). Literature in language education. Palgrave Macmillan.

Hall, G. (2015). Recent developments in uses of literature in language teaching. In M. Teranishi, Y. Saito, K. Wales (Ed.), Literature and language learning in the EFL classroom (pp. 13-25). Palgrave Macmillan. https://doi.org/10.1057/9781137443663_2

Harmer, J. (2007). The practice of English language teaching. Longman.

Helton, C. A., Asamani, J. \& Thomas, E. D. (1998). A 'Novel' approach to the teaching of reading. Tennessee State University.

Hirvela, A. (2004). Connecting reading and writing in second language writing instruction. Ann Arbor, MI: The University of Michigan Press. https://doi.org/10.3998/mpub.23736

Jones, R. (1980). An ABC of English teaching. Heinemann.

Kim, M. (2004). Literature discussions in adult SL learning. Language and Education, $18(2), 145-166$.

Kintsch, W. (2005). An overview of top-down and bottom-up effects in comprehension: The CI perspective. Discourse Processes, 39(2-3), 125-128.

Koda, K. (1992). The effects of lower-level processing skills on FL reading performance: Implications for instruction. The Modern Language Journal, 76, 502-512. https://doi.org/10.1111/j.15404781.1992.tb05400.x

Koda, K. (2007). Reading and language learning: Crosslinguistic constraints on second language reading development. Language Learning, 57, 1-44. http://dx.doi.org/10.1111/0023-8333.101997010-i1 
Kramsch, C. (2009). The multilingual subject. Oxford University Press.

Kuze, K. (2015). Using short stories in university composition classrooms. In M. Teranishi, Y. Saito, K. Wales (Ed.), Literature and language learning in the EFL classroom (pp. 182-196). Palgrave Macmillan. https://doi.org/10.1057/9781137443663_13

Lantolf, J. (2000). Sociocultural theory and second language learning. Oxford University Press

Larsen-Freeman, D. \& Anderson, M. (2011). Techniques and principles in language teaching (3rd Ed.). Oxford University Press.

Leclercq, M. (2002). Theoretical aspects of the main components and functions of attention. In M. Leclercq, P. Zimmermann (Ed.), Applied neuropsychology of attention: Theory, diagnosis and rehabilitation (pp. 3-55). Psychology Press.

Lozanov, G. (1978). Suggestology and Suggestopedia-Theory and practice. United Nations Education, Scientific and Cultural Organization.

McKay, S. (2014). Literature as content for language teaching. In M. Celce-Murcia, D. M. Brinton, M. A. Snow (Ed.), Teaching English as a second or foreign language (4th Ed.) (pp. 488-500). MA: National Geographic Learning/Heinle Cengage Learning.

Morris, J. D. (1972). Intensive reading. ELT Journal, 26, 38-47, https://doi.org/10.1093/elt/XXVII.1.38

Myonghee, K. (2004). Literature discussions in adult L2 learning. Language and Education, 18(2), 145-166. https://doi.org/10.1080/09500780408666872

Naji, J., Subramaniam, G. \& White, G. (2019). New approaches to literature for language learning. Palgrave Macmillan.

Nassaji, H. (2003). Higher-level and lower-level text processing skills in advanced ESL reading comprehension. The Modern Language Journal, 87, 261-276. https://doi.org/10.1111/1540-4781.00189

Nation, I. S. P. \& Macalister, J. (2020). Teaching ESL/EFL reading and writing (2nd Ed.). Routledge.

Par, L. (2018). The EFL students' critical reading skills across cognitive styles. JEELS, 5(1), 73-96.

Paran, A. (2008).The role of literature in instructed foreign language learning and teaching: An evidence-based survey. State of the art article. Language Teaching, 41(4), 465-496.

Pressley, M. (2002). Reading instruction that works: The case for balanced reading (2nd Ed.). Guilford. 
$\begin{array}{lllll}\text { Reviews from } & a & \text { Serial } & \text { (2020). }\end{array}$ https://www.goodreads.com/book/show/14221931-the-mark-on-the-wall.

Rumelhart, D. (1980). Schemata: The building blocks of cognition. In R. Spiro, B. Bruce, W. Brewer (Ed.), Theoretical issues in reading comprehension (pp.33-58). Erlbaum Association.

Sage, H. (1987). Incorporating literature in ESL instruction. Prentice-Hall.

Schmidt, R. (1990). The role of consciousness in second language learning. Applied Linguistics, 11, 129-158.

Scott, V. M. \& Huntington, J. A. (2007). Literature, the interpretive mode and novice learners. The Modern Language Journal, 91(1), 3-14.

Spack, R. (1985). Literature, reading, writing, and ESL: Bridging the gaps. TESOL Quarterly, 19(4), 703-721.

Stern, S. (1991). An integrated approach to literature in ESL/EFL in teaching English as a second or foreign language. Boston: Heinle \& Heinle Publishers.

Tompkins, P. J. (1994). Reader-response criticism. John Hopkins University Press.

Tseng, F. (2010). Introducing literature to an EFL classroom: Teacher's presentations and students' perceptions. Journal of Language Teaching and Research, 1(1), 53-65. https://doi.org/10.4304/j1tr.1.1.53-65

Woolf, V. (1921). The mark on the wall. Harcourt, Brace and Company, Inc.

\section{Appendix}

1. Justine - December 20, 2010, at 10:05 pm

"I think that my favourite part of this text was the fact that the mark was so mundane yet so present, like a distraction that she was desperately trying to escape yet somehow drawn to."

\section{Julia Di Piazza - Nov 22, 2012}

"With its stream of consciousness sort of style, "The Mark on the Wall" at first is a little chaotic to read. I think Virginia Woolf used this style of writing in order to purposely create that disorganized feeling for the reader, so they could feel the same way the narrator feels in this piece. I get the sense that she is questioning everything; reality, vision, history, time, objects, gender roles, life, death, etc. Overall, I get an overwhelming feeling of helplessness from this story, like the narrator realizes that we have no control over our lives and fate. She relates the way life moves to the speed of a train and talks about how fast life goes by.... I think she realizes that life will pass her by if she stays in one spot for too long wondering about a mark on the wall but she doesn't know what to do about it." 